\title{
A Comparative Study on the Problems and Prospects of Women Entrepreneurship in the Districts of Kurnool and Ananthapuramu
}

\author{
B. Parimala Devi \\ Lecturer, Department of Commerce, K. V. R Government College, Kurnool, Andhra Pradesh, India
}

\begin{abstract}
Women entrepreneurship has been recognized as an important source of economic growth. However, they still represent a minority of all entrepreneurs. Women entrepreneurs often face gender-based barriers to starting and growing their businesses, like discriminatory property, matrimonial and inheritance laws and/or cultural practices, lack of access to formal finance mechanisms limited mobility and access to information and networks, etc. This Paper represents a comparative study of problems faced by the women entrepreneurs in the districts of Kurnool and Ananthapuramuu districts of Andhra Pradesh state in India. The study reveals that there is no significant difference between the various problems faced by the women entrepreneurs in both the districts.
\end{abstract}

Keywords: Women entrepreneurship, Training, Development

\section{Introduction}

In the Globalised world, women entrepreneurs are playing a vital role and they have become important part of the global quest for the sustained economic development and social progress. Women entrepreneurs are key players in the economic development of a Nation. Women entrepreneurship has been recognized as an prominent source of economic growth. Women in the present day have been recognized as an integral part of the global struggle for economic development. Women entrepreneurship can contribute to the economic well being of the family and communities, poverty reduction and women empowerment, there by contributing to the Millennium Development Goals (MDGs). Thus, governments across the globe as well as various developmental organizations are actively undertaking promotion of women entrepreneurs through various schemes, programmes, incentives and promotional measures.

Despite of various measures taken by the government in India, there is a huge gap between the number of women entrepreneurs and male entrepreneurs. Women entrepreneurs compose least portion of total entrepreneurial activity in the entire Nation. This is due to various problems that women have to face in establishing and running a business enterprise. Hence, this study is undertaken to present an overview of practical problems that are encountered by the women entrepreneurs.

\section{Review of Literature}

\section{Indian Perspective}

1) V Krishnamoorthy and R Balasubramani (April 2014), studied various factors that motivated the women for undertaking the entrepreneurial activity. The study reported that the motivational factors which had a great impact over entrepreneurial success are ambition, independence, skills and knowledge and family support.

2) Vatharkar (2012) studied the problems encountered by the women entrepreneurs in Pune district. The study identified various managerial problems such as lack of motivation and role conflict. Other problems include difficulty in balancing work and life by the women, discriminating treatment in the society and lack of knowledge of updated government rules and regulations.

3) Anita TripathyLal,s(November 15, 2012) studied the evolution of of Women Entrepreneurs in India. The progress of women entrepreneurship was studied under four different periods ie Pre-Independence Period (before 1947), Post-Independence Period (after 1947), PostLiberalization Period (after 1991) and Post -Global Recession period (2008 onwards). The study also high lightened the importance of Women Entrepreneurship.

\section{International Perspective}

\section{Empirical Research Literature}

1) LeylaSarfaraz, NezameddinFaghih and Armaghan Asadi Majd (2014) in their study highlightened gender composition and female entrepreneurship as the significant factors affecting the economic development of any Nation. Theyshowed the relationship between gender-related development indices (introduced by the United Nations) and different stages of women entrepreneurial activity (created by Global Entrepreneurship Monitor, GEM) and suggested that female entrepreneurial activity is not significantly correlated with gender equality.

2) Jennifer E. Jennings, Candida G. Brush (2013) observed that the women entrepreneurship may be as a result of family obligations or may be due to the availability of oppurtunities. The study also pointed that the entrepreneurship is a gender phenomena. Women undertake entrepreneurship activity beyond the economic gain.

\section{Need for the Study}

Kurnool and Ananthapuramu Districts in the state of Andhra Pradesh are backward and drought prone areas. The women in kurnool and Ananthapuramu region are economically poor with poor access to Education and development 


\section{International Journal of Science and Research (IJSR) \\ ISSN (Online): 2319-7064 \\ Index Copernicus Value (2013): 6.14 | Impact Factor (2014): 5.611}

incentives offered by the Government. Women undertake less than $10 \%$ of the total entrepreneurial activity in these districts, this indicates that there is an imbalance in the ratio of men entrepreneurship and women entrepreneurship in the districts. This is due to the backwardness of women in the aspects of economic and social awareness. Another reason for the slow growth rate in women entrepreneurs are the problems that women face in establishing and operating a business unit of their own. Women face lot of problems in the process of becoming an entrepreneur. No research has been done on the problems and prospects of women entrepreneurship in Kurnool and Ananthapuramu districts. The findings of this study may enable the policy makers in initiating the required measures for the development of women entrepreneurship in these districts.

\section{Objectives of the Study}

1) Investigating the socio-economic status of the women entrepreneurs in Kurnool and Ananthapuramu.

2) Exploring the problems of the women entrepreneurs in Kurnool and Ananthapuramu.

\section{Research Methodology}

The study is mainly based on primary data collected through field investigation. A sample of 150 women entrepreneurs have been chosen at random for the study . 75 women entrepreneurs from Kurnool district and 75 women entrepreneurs from Ananthpuramu district have been selected. In Kurnool district there are three revenue divisions Kurnool, Adoni and Nandyal. 25 entrepreneurs were selected on random in each revenue division amounting to a total of 75, In Ananthapuramu there are three revenue divisions namely Anantapur, Dharmavarm and Penukonda. 25 entrepreneurs were selected on random in each revenue division amounting to a total of 75. After elimination of few partially filled questionnaires, the resultant sample size is 142 The entrepreneurs were personally interviewed with the help of "questionnaire", specially designed for the purpose. In addition to the primary data, secondary data was also collected from agencies like DIC, APIIC and CPO, etc. The data so collected was properly analyzed with the help of simple statistical tools such as chi- square tests, mean and percentages.

\section{1) Socio - Economic profile of Women Entrepreneurs}

Table 1.1: Social Category

\begin{tabular}{|c|c|c|c|}
\hline & Kurnool & Anantapuramu & Total \\
\hline OC & 24 & 29 & 53 \\
\hline & $35.3 \%$ & $39.2 \%$ & $37.3 \%$ \\
\hline BC & 16 & 14 & 30 \\
\hline & $23.5 \%$ & $18.9 \%$ & $21.1 \%$ \\
\hline SC & 19 & 22 & 41 \\
\hline & $27.9 \%$ & $29.7 \%$ & $28.9 \%$ \\
\hline ST & 9 & 9 & 18 \\
\hline & $13.2 \%$ & $12.2 \%$ & $12.7 \%$ \\
\hline & 68 & 74 & 142 \\
\hline & $100.0 \%$ & $100.0 \%$ & $100.0 \%$ \\
\hline
\end{tabular}

Table No 1.1 shows that 35\% of the respondents in Kurnool district and $39 \%$ of the respondents in Ananthapuramu district come under the category of OC. Chi-square statistics $=.572$, reveals that there is no significant difference between two districts regarding social category as $\mathrm{p}=.903$. with $\alpha=$ 0.05 .

Table 1.2: Annual Income

\begin{tabular}{|c|c|c|c|}
\hline & Kurnool & Anantapuramu & Total \\
\hline$<250000$ & 37 & 27 & 64 \\
\hline & $54.4 \%$ & $36.5 \%$ & $45.1 \%$ \\
\hline $250000-500000$ & 21 & 19 & 40 \\
\hline & $30.9 \%$ & $25.7 \%$ & $28.2 \%$ \\
\hline $500001-750000$ & 5 & 13 & 18 \\
\hline & $7.4 \%$ & $17.6 \%$ & $12.7 \%$ \\
\hline $750001-1000000$ & 4 & 8 & 12 \\
\hline & $5.9 \%$ & $10.8 \%$ & $8.5 \%$ \\
\hline$>1000000$ & 1 & 7 & 8 \\
\hline & $1.5 \%$ & $9.5 \%$ & $5.6 \%$ \\
\hline & 68 & 74 & 142 \\
\hline & $100.0 \%$ & $100.0 \%$ & $100.0 \%$ \\
\hline
\end{tabular}

Table No1.2 shows that $54 \%$ of the respondents in Kurnool district and $37 \%$ of the respondents in Ananthapuramu district have annual income less than 250000. 2\% of the respondents in Kurnool district and $10 \%$ of the respondents in Ananthapuramu district have annual income more than 1000000 . Chi-square statistics $={ }^{\prime} 10.817$ reveals that there is significant difference between two districts regarding annual income as $\mathrm{p}=.029$. with $\alpha=0.05$.

Table 1.3: Annual rate of profitability

\begin{tabular}{|c|c|c|c|}
\hline & Kurnool & Anantapuramu & Total \\
\hline$<10 \%$ & 18 & 8 & 26 \\
\hline & $26.5 \%$ & $10.8 \%$ & $18.3 \%$ \\
\hline $10-20 \%$ & 22 & 22 & 44 \\
\hline & $32.4 \%$ & $29.7 \%$ & $31.0 \%$ \\
\hline $21-30 \%$ & 15 & 17 & 32 \\
\hline & $22.1 \%$ & $23.0 \%$ & $22.5 \%$ \\
\hline $31-40 \%$ & 8 & 20 & 28 \\
\hline & $11.8 \%$ & $27.0 \%$ & $19.7 \%$ \\
\hline$>40 \%$ & 5 & 7 & 12 \\
\hline & $7.4 \%$ & $9.5 \%$ & $8.5 \%$ \\
\hline & 68 & 74 & 142 \\
\hline & $100.0 \%$ & $100.0 \%$ & $100.0 \%$ \\
\hline
\end{tabular}

Table No 1.3 shows that $33 \%$ of the respondents in Kurnool district and $30 \%$ of the respondents in Ananthapuramu district have annual rate of profitability between $10-20 \%$. $5 \%$ of the respondents in Kurnool district and $7 \%$ of the respondents in Ananthapuramu district have annual rate of profitability more than $40 \%$. Chi-square statistics $=9.210$ reveals that there is no significant difference between two districts regarding annual rate of profitability as $\mathrm{p}=.056$. with $\alpha=0.05$.

\section{2) Problems of women entrepreneurs in the study area}

Table 2.1: Problems relating to Formation

\begin{tabular}{|c|c|c|c|c|}
\hline & \multicolumn{2}{|c|}{ Kurnool } & \multicolumn{2}{c|}{ Anantapuramu } \\
\cline { 2 - 5 } Type of Problems & Mean & Rank & Mean & Rank \\
\hline $\begin{array}{c}\text { Problem in Registration of the } \\
\text { Business }\end{array}$ & 1.72 & 3 & 1.99 & 2 \\
\hline Lengthy Legal Formalities & 2.00 & 2 & 1.81 & 3 \\
\hline $\begin{array}{c}\text { Administrative Delay in the } \\
\text { process of Registration }\end{array}$ & 2.15 & 1 & 2.45 & 1 \\
\hline
\end{tabular}




\section{International Journal of Science and Research (IJSR) \\ ISSN (Online): 2319-7064 \\ Index Copernicus Value (2013): 6.14 | Impact Factor (2014): 5.611}

Table No 2.1 reveals that problem of administrative delay in the process of registration ranked first in both the districts of Kurnool and Ananthapuramu. problem of Lengthy legal formalities in Kurnool district and the problem in the registration of the business Ananthapuramu district ranked second.

Table 2.2: Problems relating to Finance

\begin{tabular}{|c|c|c|c|c|}
\hline \multirow{2}{*}{ Type of Problems } & \multicolumn{2}{|c|}{ Kurnool } & \multicolumn{2}{|c|}{ Anantapuramu } \\
\cline { 2 - 5 } & Mean & Rank & Mean & Rank \\
\hline $\begin{array}{c}\text { Problem in procuring } \\
\text { the Capital }\end{array}$ & 4.19 & 1 & 3.85 & 2 \\
\hline High Rate of Interest & 1.94 & 5 & 2.15 & 4 \\
\hline $\begin{array}{c}\text { Insufficient Collateral } \\
\text { Security }\end{array}$ & 2.24 & 4 & 1.69 & 5 \\
\hline $\begin{array}{c}\text { Delay in Sanctioning } \\
\text { of Bank Loan }\end{array}$ & 4.15 & 2 & 4.19 & 1 \\
\hline $\begin{array}{c}\text { Insufficient Financial } \\
\text { Assistance from the } \\
\text { government }\end{array}$ & 2.81 & 3 & 2.74 & 3 \\
\hline
\end{tabular}

Table No 2.2 reveals that Problem in procuring the Capital ranked first in Kurnool District and it is ranked second in Ananthapuramu district. Delay in Sanctioning of Bank Loan ranked first in Ananthapuramu district and it is ranked second in Kurnool District.

Table 2.3: Problems relating to Raw material

\begin{tabular}{|c|c|c|c|c|}
\hline \multirow{2}{*}{ Type of Problems } & \multicolumn{2}{|c|}{ Kurnool } & \multicolumn{2}{c|}{ Anantapuramu } \\
\cline { 2 - 5 } & Mean & Rank & Mean & Rank \\
\hline Scarcity & 2.07 & 4 & 2.33 & 4 \\
\hline High Cost & 3.897 & 1 & 1.63 & 5 \\
\hline Low Quality & 1.57 & 5 & 2.44 & 3 \\
\hline Transportation & 2.38 & 3 & 4.219 & 1 \\
\hline Irregular supply & 3.78 & 2 & 3.81 & 2 \\
\hline
\end{tabular}

Table No. 2.3 reveals that high cost of raw material ranked first in Kurnool District and problem of transportation ranked first in Ananthapuramu District. Problem of irregular supply of raw material ranked second in both the districts.

Table 2.4: Problems relating to Labour

\begin{tabular}{|c|c|c|c|c|}
\hline \multirow{2}{*}{ Type of Problems } & \multicolumn{2}{|c|}{ Kurnool } & \multicolumn{2}{c|}{ Anantapuramu } \\
\cline { 2 - 5 } & Mean & Rank & Mean & Rank \\
\hline High Turn Over & 3.18 & 2 & 1.59 & 4 \\
\hline Unionization & 1.62 & 4 & 1.89 & 3 \\
\hline Lack of Trained labour & 3.47 & 1 & 3.33 & 1 \\
\hline Low Efficiency & 1.69 & 3 & 3.22 & 2 \\
\hline
\end{tabular}

Table No. 2.4 shows that lack of trained labour ranked first in both the districts. High labour turn over is ranked second in Kurnool district and Low efficiency of labour is ranked second in Ananthapuramu District.

Table 2.5: Problems relating to Marketing

\begin{tabular}{|c|c|c|c|c|}
\hline \multirow{2}{*}{ Type of Problems } & \multicolumn{2}{|c|}{ Kurnool } & \multicolumn{2}{c|}{ Anantapuramu } \\
\cline { 2 - 5 } & Mean & Rank & Mean & Rank \\
\hline Competition & 3.68 & 1 & 3.67 & 2 \\
\hline Distribution Controls & 2.85 & 3 & 2.64 & 4 \\
\hline Transport & 2.26 & 4 & 2.14 & 5 \\
\hline Price Control & 2.12 & 5 & 3.14 & 3 \\
\hline Low Market Demand & 3.12 & 2 & 4.32 & 1 \\
\hline
\end{tabular}

Table No 2.5 reveals that Competition in market ranked first in Kurnool district and second in Ananthapuramu district. Problem of low market demand ranked first in Ananthapuramu district and second in Kurnool district.

Table 2.6: Problems relating to Technology

\begin{tabular}{|c|c|c|c|c|}
\hline \multirow{2}{*}{ Type of Problems } & \multicolumn{2}{|c|}{ Kurnool } & \multicolumn{2}{c|}{ Anantapuramu } \\
\cline { 2 - 5 } & Mean & Rank & Mean & Rank \\
\hline Lack of Updated Technology & 5.26 & 1 & 4.75 & 1 \\
\hline High Cost & 1.97 & 3 & 2.03 & 4 \\
\hline $\begin{array}{c}\text { Lack of Technical assistance from the } \\
\text { Government }\end{array}$ & 1.91 & 4 & 2.45 & 3 \\
\hline Lack of Technical Training & 4.44 & 2 & 4.37 & 2 \\
\hline
\end{tabular}

Table No. 2.6 shows that problem of lack of updated technology is ranked first in both the districts. Lack of technical training ranked second in both the districts.

Table 2.7: Problems relating to Management

\begin{tabular}{|c|c|c|c|c|}
\hline \multirow{2}{*}{ Type of Problems } & \multicolumn{2}{|c|}{ Kurnool } & \multicolumn{2}{c|}{ Anantapuramu } \\
\cline { 2 - 5 } & Mean & Rank & Mean & Rank \\
\hline Limited Managerial Ability & 4.18 & 1 & 4.26 & 1 \\
\hline Lack of professional managers & 4.00 & 2 & 3.21 & 6 \\
\hline High cost & 3.44 & 4 & 3.36 & 4 \\
\hline Weak Bargaining Power & 3.41 & 5 & 3.37 & 3 \\
\hline Low Risk taking attitude & 1.91 & 7 & 2.45 & 7 \\
\hline Lack of Systematic planning & 3.18 & 6 & 3.26 & 5 \\
\hline Low Level of Self Confidence & 3.47 & 3 & 3.71 & 2 \\
\hline
\end{tabular}

Table No 2.7 depicts that limited managerial ability is ranked first in both the districts. Lack of professional managers is ranked second in kurnool district and Low level of self confidence is ranked second in Ananthapuramu district.

Table 2.8: Problems relating to Infrastructural Facilities

\begin{tabular}{|c|c|c|c|c|}
\hline \multirow{2}{*}{\begin{tabular}{c} 
Type of Problems \\
\cline { 2 - 5 }
\end{tabular}} & \multicolumn{2}{|c|}{ Kurnool } & \multicolumn{3}{c|}{ Anantapuramu } \\
\hline Lack of proper Transportation Facilities & 2.97 & 2 & 3.03 & 1 \\
\hline $\begin{array}{c}\text { Lack of proper Communication } \\
\text { Facilities }\end{array}$ & 1.97 & 3 & 2.03 & 3 \\
\hline Lack of proper Warehouse Facilities & 3.41 & 1 & 1.96 & 4 \\
\hline Lack of proper Banking Facilities & 1.62 & 4 & 3.00 & 2 \\
\hline
\end{tabular}

Table No 2.8 shows that lack of proper warehouse facilities is ranked first in kurnool district and fourth in Ananthapuramu district. Lack of proper transportation facilities ranked first in Ananthapuramu District and second in Kurnool district.

Table 2.9: Problems relating to Family

\begin{tabular}{|c|c|c|c|c|}
\hline \multirow{2}{*}{ Type of Problems } & \multicolumn{2}{|c|}{ Kurnool } & \multicolumn{2}{c|}{ Anantapuramu } \\
\cline { 2 - 5 } & Mean & Rank & Mean & Rank \\
\hline Lack of Family Support & 3.163 & 2 & 2.843 & 3 \\
\hline $\begin{array}{c}\text { Problem in balancing the family } \\
\text { and Business }\end{array}$ & 2.657 & 3 & 3.292 & 2 \\
\hline $\begin{array}{c}\text { Interference of family members } \\
\text { in Business matters }\end{array}$ & 2.137 & 4 & 2.129 & 4 \\
\hline Problem in Children Care & 3.219 & 1 & 3.817 & 1 \\
\hline
\end{tabular}

Table No 2.9 shows that Problem in Children Care ranked first in both the districts. Lack of Family Support is ranked second in Kurnool district and Problem in balancing the 


\section{International Journal of Science and Research (IJSR) \\ ISSN (Online): 2319-7064 \\ Index Copernicus Value (2013): 6.14 | Impact Factor (2014): 5.611}

family and Business ranked second in Ananthapuramu district.

Table 2.10: Regional Problems

\begin{tabular}{|c|c|c|c|c|}
\hline \multirow{2}{*}{ Type of Problems } & \multicolumn{2}{|c|}{ Kurnool } & \multicolumn{2}{c|}{ Anantapuramu } \\
\cline { 2 - 5 } & Mean & Rank & Mean & Rank \\
\hline Male Dominance & 2.19 & 1 & 2.60 & 1 \\
\hline Social Customs and Traditions & 1.82 & 3 & 1.78 & 2 \\
\hline Political Domination & 1.97 & 2 & 1.63 & 3 \\
\hline
\end{tabular}

Table No 2.10 shows that problem of Male Dominance ranked first in both the districts. Problem of Political Domination ranked second in Kurnool district. Problem of Social Customs and Traditions ranked second in Ananthapuramu district.

Table 2.11: Problems relating to Health

\begin{tabular}{|c|c|c|c|c|}
\hline \multirow{2}{*}{ Type of Problems } & \multicolumn{2}{|c|}{ Kurnool } & \multicolumn{2}{c|}{ Anantapuramu } \\
\cline { 2 - 5 } & Mean & Rank & Mean & Rank \\
\hline Limited Physical Capacity & 1.59 & 2 & 2.84 & 1 \\
\hline Mental stress & 2.76 & 1 & 1.71 & 2 \\
\hline C. Common Health Problems & 1.47 & 3 & 1.62 & 3 \\
\hline
\end{tabular}

Table No 2.11 shows that Problem of Mental stress ranked first in Kurnool district and second in Ananthapuramuu district. Limited Physical Capacity ranked first in Ananthapuramu district and second in Kurnool district.

\section{Findings of the Study}

\section{Socio-Economic Profile of Women Entrepreneurs}

1) $35 \%$ of the respondents in Kurnool district and 39\% of the respondents in Ananthapuramu district come under the category of OC.

2) $54 \%$ of the respondents in Kurnool district and $37 \%$ of the respondents in Ananthapuramu district have annual income less than 250000.

3) $33 \%$ of the respondents in Kurnool district and $30 \%$ of the respondents in Ananthapuramu district have annual rate of profitability between $10-20 \%$.

\section{Problems encountered by the Women Entrepreneurs}

1) Administrative delay in the process of registration is the major problem faced by the women entrepreneurs in both the districts of Kurnool and Ananthapuramu in connection with the formation of the business.

2) Problem in procuring the Capital is the main problem with respect to capital in Kurnool district. Where as delay in Sanctioning of Bank Loan is the major problem in Ananthapuramu district.

3) Women entrepreneurs in Kurnool district face the problem of high cost of raw material and in Ananthapuramu district the main problem with respect to raw material is Transportation.

4) Women entrepreneurs in both the districts face the problem of lack of trained labour in common as a problem relating to labour.

5) In respect of market conditions competition is the key problem in Kurnool district and low market demand is the main problem in Ananthapuramu district.
6) Lack of updated technology is the main problem faced by the women entrepreneurs followed by the problem of lack of technical training in both the districts.

7) Women entrepreneurs in both the districts face the problem of limited managerial ability and professional skills in management of the business.

8) As per the infrastructural facilities are concerned lack of proper warehouse facilities is the main problem in Kurnool district, lack of transport facilities is the main problem in Ananthapuramu district.

9) Problem in Children Care is the key problem faced by the women entrepreneurs in both the districts in common.

10) Male dominance is the major problem faced by the women entrepreneurs in both the districts. Problem of Political Domination ranked second in Kurnool district. Problem of Social Customs and Traditions ranked second in Ananthapuramu district.

11) In relation to health, Problem of Mental stress ranked first in Kurnool district and second in Ananthapuramu district. Limited Physical Capacity ranked first in Ananthapuramu district and second in Kurnool district.

\section{Recommendations}

The problems of women entrepreneurs are multifarious and multidimensional. Some recommendations to solve the problems of women entrepreneurs are as follows.

1) Procedural simplification : The procedures and formalities should be simplified for registration of business and for getting financial and legal assistance, subsidies, concessions, relief etc, from different government and non-governmental departments.

2) Financial Cells : Speical financial cells may be opened for providing easy finance to women entrepreneurs in various public financial institutions and banks. These cells should be manned by women staff. These cells should provide complete guidance to the women in procuring the finance.

3) Marketing Coopratives : Encouragement and assistance should be provided to women entrepreneurs for setting up cooperatives. These cooperative will pool the inputs of women enterprises and sell them on remunerative prices. Such cooperative will help to eliminate the middlemen. These cooperatives should assist women entrepreneurs in quality standards, by providing information of foreign markets as well as by assisting them in overseas representation.

4) Supply of Raw Materials : Government should take necessary measures in order to ensure availability of Scarce and imported raw materials to women entrepreneurs on priority basis. Subsidies may be given to the products manufactured by women entrepreneurs as cost effective measure.

5) Training Facilities : Training is essential for the development of entrepreneurship. Training schemes should be so designed that women can take full advantage. Training should be imparted in all the aspects of business management such as management skills, technical skills and marketing skills.

6) Access to Infrastructure : Government can set some priorities for women entrepreneurs for allocation of 


\section{International Journal of Science and Research (IJSR) \\ ISSN (Online): 2319-7064 \\ Index Copernicus Value (2013): 6.14 | Impact Factor (2014): 5.611}

industrial plots, sheds and basic infrastructure/amenities. Investments in infrastructure networks by women should be encouraged. Waiver on stamp duty and registration charges for Women to create their properties should be offered.

7) Awareness Programmes : The government should conduct awareness campaigns on the issues of women such as women empowerment, motivation , personality development and health management. Such programmes should be conducted in the educational institutions also in order to provide awareness to the women students reagarding entrepreneurship.

8) Seminars: More seminars, conferences and workshops on women entrepreneurship should be organized. Women should be encouraged to participate in them and express their views. Seminars should also be conducted in the rural areas.

9) Change in the Attitude: The attitude of the family members and the society should be changed towards the working women. Women should change their attitude about themselves. They should be self confident in their approach.

10) Awareness of Constitutional and Legal Rights: Women should be made aware of their constitutional and legal rights both in their personal and in the social sphere.

11) Grievance Redressal Cell: Separate grievance cell should be established in the District Industries Centre for quick redressal of various problems faced by the women entrepreneurs in the matters relating to the business.

\section{References}

[1] V Krishnamoorthy and R Balasubramani, 2014 MOTIVATIONAL FACTORS AMONG WOMEN ENTREPRENEURS AND THEIR ENTREPRENEURIAL SUCCESS: A STUDY issn 2319-345x www.ijmrbs.comvol. 3, no. 2.

[2] Vatharkar, P. (2012). A study of constraints and motivating factors for Indian women entrepreneurs in small scale industries. Paper presented at The 2012 International Conference on Business and Management, Phuket-Thailand, 67 September (pp. 473-489).

[3] Anita TripathyLal(November 15, 2012)—Women Entrepreneurs in India - Over the Years!\| Fore School of Management

[4] Meenu Goyal, Jai Parkash (2011), Women Entrepreneurship in India-problems and prospects, International Journal of Multidisciplinary Research, 1(5).

[5] J. McGrath Cohoon Vivek Wadhwa Lesa Mitchell May 2010The Anatomy of an Entrepreneur Are Successful Women Entrepreneurs Different From Men? (book)

[6] Shodh, Samiksha aur Mulyankan (International Research Journal)-ISSN-0974-2832Vol. II, Issue-9-10 (Oct.-Nov.-2009) 13 Research Paper-Commerce \& Management Entrepreneurship

[7] Jyothi and Prasad (2009)A N ANALYTICAL STUDY OF THE IMPACT OF WOMEN ENTREPRENEURSHIP DEVELOPMENT MEASURES PROMOTED BY THE GOVERNMENT AND FINANCIAL INSTITUTIONS IN KERALA
[8] Veena S. Samani, (2008), -A Study of Women Entrepreneurs Engaged in Food Processing\|, Thesis submitted to SaurashtraUniversity for the degree of doctor of philosophy in Home Science.

[9] Singh,SurinderPal,(2008) An Insight Into The Emergence Of Women-owned Businesses As An Economic Force In India, presented at Special Conference of the Strategic Management Society, December 12-14, 2008,

[10] Lall,Madhurima,andSahaiShikha(2008) Lall, Madhurima, \& Sahai Shikha, 2008, Women in Family Business, presented at first Asian invitational conference on family business at Indian School of Business, Hyderabad.

[11] LeylaSarfaraz, NezameddinFaghih and ArmaghanAsadiMajd (2014) ,-The relationship between women entrepreneurship and genderequalityll Journal of Global Entrepreneurship Research, 2:6 doi:10.1186/2251-7316-2-6.

[12] Ekesionye E. N and Okolo A. N5 January, 2012, -Women empowerment and participation in economic activities: Indispensabletools for self- reliance and development of Nigerian society\| Research and Review Vol. 7(1), pp. 10-18 